\title{
RANCANG BANGUN SISTEM RESERVASI RUANGAN MENGGUNAKAN NEAR FIELD COMMUNICATION (NFC) BERBASIS MIKROKONTROLER
}

\author{
Rahmad Fadhil, Mohammad Hafiz Hersyah, MT \\ Jurusan Sistem Komputer,FTI Universitas AndalasLimau Manis Kec. Pauh, Kota Padang, Sumatera Barat 25163 INDONESIA
}

\section{ARTICLE INFORMATION}

Received: August $4^{\text {th }}, 2020$

Revised: September $26^{\text {th }}, 2020$

Available online: September $30^{\text {th }}, 2020$

\begin{tabular}{l} 
KEYWORDS \\
\hline Room, NFC, website, microcontroler \\
CORRESPONDENCE \\
\hline Phone: 082383478937 \\
E-mail: mhafiz@fti.unand.ac.id
\end{tabular}

\begin{abstract}
Current technological developments also help in the ordering system. Simplifying the reservation system with information technology is one of the innovations made to help users of the room more easily in booking a room. The system designed consists of hardware and software connected to book a room based on, UID, usage time and to open the door of the room. Hardware includes Arduino Mega, NFC tags, NFC readers, relays, solenoids, buzzers, and LEDs. The software includes a Mysql website and database. The system will store user data, date, shift, length of usage and type of room booked by the user. NFC tags will be used by the customer to open the door to the room by getting closer to the NFC reader. This system aims to facilitate the process of borrowing space without having to undergo a convoluted process. Due to the description explained, this research is focussing on room reservation.
\end{abstract}

Keywords: Room, NFC, website, microcontroler

\section{PENDAHULUAN}

Universitas Andalas sangat terkenal dengan sebutan kampus hijau. Di kampus ini dilahirkan aktivis-aktivis yang memiliki banyak kegiatan positif tentunya. Banyaknya acara di luar jam kerja yang membutuhkan ruangan kelas, membuat pengguna harus meminjam terlebih dahulu ruangan yang akan dipakai. Proses peminjaman selama ini masih tergolong manual, yaitu dengan cara mendatangi bagian umum pelayanan sarana dan prasarana untuk mendaftarkan diri sebagai pengguna ruangan dalam satu kali penggunaan. Jika ingin menggunakan lagi maka pengguna juga harus kembali mendatangi biro rumah tangga dan melakukan proses tersebut secara berulang ulang setiap kali mau menggunakan ruangan.

Teknologi NFC menggunakan teknologi identifikasi frekuensi radio (RFID) untuk melakukan pertukaran data standar non-kontak antara dua perangkat NFC. Sebelumnya, teknologi RFID sangat umum digunakan dalam kartu kontrol akses contactless, tag elektronik dan system lainnya. Teknologi NFC secara bertahap menjadi terintegrasi dalam smartphone yang secara langsung dapat membaca tag NFC dalam sebuah pesan, seperti, misalnya: nomor kartu kredit, nomor kartu perjalanan dan catatan transaksi yang dapat disimpan dalam tag NFC. Hasil komunikasi NFC ini juga dapat diintegrasikan ke dalam sistem keamanan akses pintu.[1].

Sistem penguncian pintu menggunakan solenoid agar dapat dikunci dan dibuka secara otomatis. Pemanfaatan solenoid ini sudah dilakukan oleh laboratorium tertanam dan robotik fakultas teknik komputer Universitas Diponegoro. Pada penelitian ini dimanfaatkan teknologi penguncian otomatis dan kontrol cahaya menggunakan Intel Galileo berbasis Internet of Things (IoT). Mereka menciptakan sebuah ruangan pintar, dimana lampu dapat dinyalakan sesuai intensitas cahaya di dalam ruangan. Selain itu, pintu ruangan tersebut juga dapat dikunci dan dibuka melalui aplikasi android [2].

Pintu menjadi objek pokok dalam penelitian ini. Dimana penelitian mengenai pintu ini juga dibahas sebelumnya dalam penelitian sistem monitoring kunci pintu ruangan menggunakan modul wi-fi. Di dalam penelitian ini, sistem yang dibuat untuk mengetahui pintu sudah terkunci atau belum menggunakan limit switch. Limit switch ini terhubung ke jaringan melalui ESP8266 sehingga pintu dapat di monitoring lewat aplikasi android [3].

Berdasarkan uraian tersebut, penelitian ini diberi judul "Rancang

Bangun Sistem Reservasi Ruangan Menggunakan NFC tag Berbasis Mikrokontroler". Dari penelitian ini diharapkan dapat mempermudah proses peminjaman ruangan di luar jam kerja dari segi waktu dan tempat. Selain itu penelitian ini juga efektif karena dengan memamfaatkan smartphone, mampu memimalisir pungli (pungutan liar) dari oknum-oknum tertentu.

\section{LANDASAN TEORI}

\section{Sistem Reservasi Ruangan}

Menurut Kurniawan (2011), sistem reservasi adalah sekumpulan elemen yang saling berhubungan dan bekerjasama untuk mendukung suatu kegiatan pemesanan atau peminjaman 
layanan bisnis tertentu sehingga dapat menghasilkan output yang sesuai dan cepat. [4]

\section{Near Field Communication (NFC)}

Near Field Communication (NFC) adalah teknologi baru yang merupakan pengembangan dari teknologi Radio Frequency Identification (RFID). NFC secara otomatis langsung dapat mengkoneksikan kedua perangkat dengan cepat sesuai kebutuhan tanpa di set terlebih dahulu. Komunikasi NFC akan terjadi ketika dua perangkat yang mendukung NFC bertemu dan salah satunya menjadi inisiator atau sebagai target. Adapun maksimum jarak komunikasi antar perangkat yaitu $4 \mathrm{~cm}$, dengan pertukaran data sepersepuluh detik [5].

\section{Arduino Mega}

Arduino Mega 2560 adalah papan pengembangan mikrokontroller yang berbasis Arduino dengan menggunakan chip ATmega2560. Board ini memiliki pin I/O yang cukup banyak, sejumlah 54 buah digital I/O pin (15 pin diantaranya adalah PWM), 16 pin analog input, 4 pin UART (serial port hardware). Arduino Mega 2560 dilengkapi dengan sebuah oscillator $16 \mathrm{Mhz}$, sebuah port USB, power jack DC, ICSP header, dan tombol reset. Board ini sudah sangat lengkap, sudah memiliki segala sesuatu yang dibuthkan untuk sebuah mikrokontroller. Dengan penggunaan yang cukup sederhana, tinggal menghubungkan power dari USB ke PC anda atau melalui adaptor AC/DC ke jack DC[6].

\section{Selenoid}

Solenoid terdiri dari lilitan kawat dan pengisap besi (plunger) yang dibiarkan bergerak melalui pusat lilitan. Ketika lilitan diberi energi,gaya magnet mendorong pengisap sehingga seluruh bagian berada di dalam lilitan. Solenoid berfungsi sebagai kunci, dengan lidah kunci yag terdapat pada solenoid dapat digunakan untuk membuka dan menutup pintu. Secara khusus, fisik solenoid memiliki panjang $55 \mathrm{~mm}$ dan sebuah armature yang ditahan dengan sebuah pegas kembali. Ketika solenoid diaktifkan dengan tegangan mencapai 9-12VDC, solenoid bergerak dan kemudian ketika tegangan dihilangkan, solenoid akan meloncat kembali ke posisi semula [7]

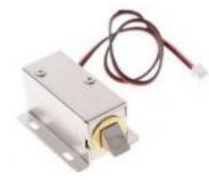

\section{Gambar 2.4 Selonoid Door lock [7]}

\section{Relay}

Relay memiliki prinsip elektromagnetik untuk menggerakkan kontak saklar, hal ini membuat relay mampu menghantarkan listrik dengan tegangan tinggi hanya dengan arus listrik yang rendah (low power) [8].

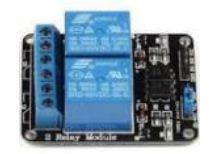

\section{Gambar 2.5 Relay 12V 10A [9]}

\section{Website}

Website (Situs Web) merupakan kumpulan dari halaman-halaman web yang berhubungan dengan file lain yang terkait. Dalam sebuah website terdapat suatu halaman yang dikenal dengan sebutan home page. Home page adalah sebuah halaman yang pertama kali dilihat ketika seseorang mengunjungi website. Dari home page, pengujung dapat mengklik hyperlink untuk pindah ke halaman lain yang terdapat dalam website tersebut [9].

\section{Buzzer}

Buzzer adalah sebuah komponen elektronika yang berfungsi untuk mengubah getaran listrik menjadi getaran suara. Pada dasarnya prinsip kerja buzzer hampir sama dengan loudspeaker. Jadi buzzer juga terdiri dari kumparan yang terpasang pada diafragma dan kemudian kumparan tersebut dialiri arus sehingga menjadi elektromagnet. Kumparan akan tertarik ke dalam atau keluar, tergantung dari arah arus dan polaritas magnetnya. Karena kumparan dipasang pada diafragma maka setiap gerakan kumparan akan menggerakkan diafragma secara bolak-balik sehingga membuat udara bergetar yang akan menghasilkan suara. Buzzer biasa digunakan sebagai indikator bahwa proses telah selesai atau terjadi suatu kesalahan pada sebuah alat (alarm) [10].

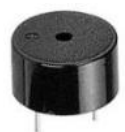

Gambar 2.7 Buzzer[10]

\section{Motor Servo}

Motor servo menggunakan sistem umpan balik tertutup, di mana posisi dari motor akan diinformasikan kembali ke rangkaian kontrol yang ada di dalam motor servo. Motor ini terdiri dari sebuah motor DC, serangkaian gear, potensiometer dan rangkaian kontrol. Potensiometer berfungsi untuk menentukan batas sudut dari putaran servo. Sedangkan sudut dari sumbu motor servo diatur berdasarkan lebar pulsa yang dikirim melalui kaki sinyal dari kabel motor. Karena motor servo merupakan alat untuk mengubah energi listrik menjadi energi mekanik, maka magnet permanen motor servolah yang mengubah energi listrik ke dalam energi mekanik melalui interaksi dari dua medan magnet. Salah satu medan dihasilkan oleh magnet permanen dan yang satunya dihasilkan oleh arus yang mengalir dalam kumparan motor. Resultan dari dua medan magnet tersebut menghasilkan torsi yang membangkitkan putaran motor tersebut. Saat motor berputar, arus pada kumparan motor menghasilkan torsi yang nilainya konstan [11].

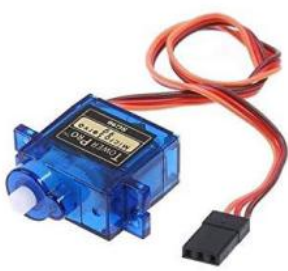

Gambar 2.1 Motor Servo [11]

\section{Database MySQL}

MySQL adalah sebuah Relational Database Management System (RDBMS) yang cepat. MySQL menggunakan Structure Query Language (SQL) sebagai standar bahasa query database. MySQL mengendalikan akses ke data-data dalam database. MySQL merupakan sebuah database server yang free, artinya kita bebas digunakan untuk keperluan pribadi atau usaha tanpa harus membeli atau membayar lisensinya. Database MySQL memiliki beberapa kelebihan dibanding database lain, diantaranya[12] : 1. MySQL merupakan sebuah database server yang free, artinya database ini bebas menggunakan database ini untuk keperluan pribadi atau usaha tanpa harus membeli atau membayar lisensinya. 
2. MySQL mampu menerima query yang bertumpuk dalam satu permintaan.

3. MySQL merupakan database yang mampu menyimpan data berkapasitas sangat besar hingga berukuran GigaByte sekalipun.

\section{RANCANGAN SISTEM}

Pada bagian ini dijelaskan rancangan umum sistem secara keseluruhan. Berikut rancangan umum sistem pemesanan kamar hotel, seperti terlihat pada Gambar 3.1

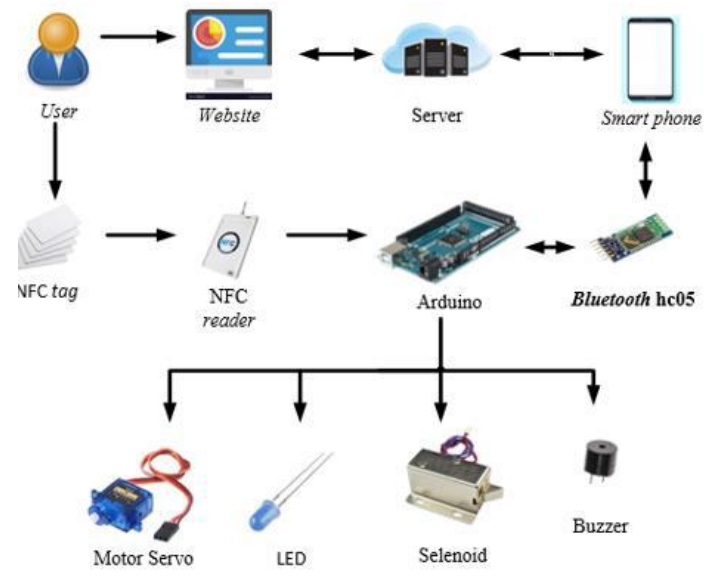

Gambar 3.1 Rancangan Umum

Berdasarkan Gambar 3.1 Pada blok diagram tersebut, gambaran sistem secara umum dapat dijelaskan bahwa pengguna akan mengakses Website terlebih dahulu. Dimana disini pengguna mendaftarkan UID yang terdapat di NFC tag yang dimiliki ke Website. Setelah terdaftar di Website maka NFC tag ini akan didekatkan ke reader yang terletak didekat pintu. Mikrokontroler akan mengirimkan UID yng dibacanya ke server melalui Bluetooth. Bluetooth akan terkoneksi ke smart phone yang memiliki jaringan internet untuk dapat terhubung ke database Jika UID nya terdaftar di database server maka mikrokontroler akan menggerakan solenoid dan motor Servo sehingga pintu terbuka. Jika tidak terdaftar maka led menyala dan buzzer berbunyi.

\section{Rancangan Perangkat Keras}

Rancangan perangkat keras yang akan diimplementasikan adalah seperti gambar 3.2 :

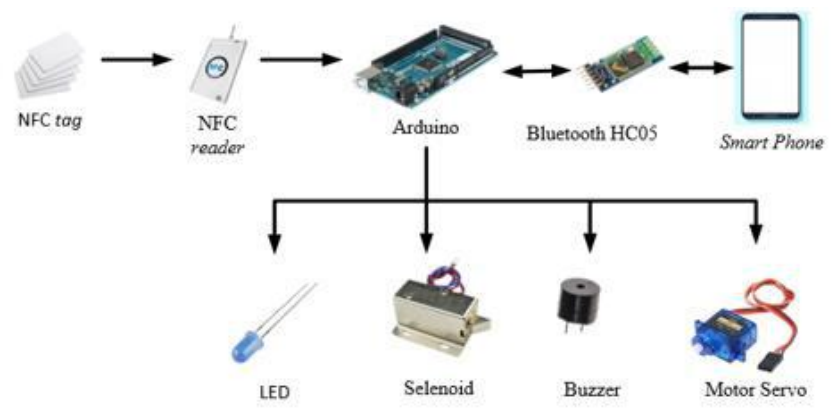

Gambar 3. 2 Rencana Rancangan Perangkat Keras

1. Dari Gambar 3.2 perancangan hardware dari sistem, sebagai berikut : NFC-tag digunakan sebagai identifier User .

2. NFC-reader berfungsi membaca UID dan data pada NFCtag.

3. Arduino berfungsi sebagai pengontrol keseluruhan sistem, yang berisikan intruksi dan logika program.

4. Bluetooth hc05 berfungsi untuk mengirim data dari arduino ke server melalui jaringan internet yang ada pada smart phone.

5. Smart phone berfungsi sebagai media penghubung ke database.
6. LED digunakan sebagai indikator notifikasi. LED yang digunakan terdiri dari dua warna, LED putih menyala sebagai tanda akses diterima, LED merah menyala sebagai tanda akses ditolak dan sebagai notifikasi jika waktu penggunaan ruangan hampir habis.

7. Selenoid digunakan sebagai pengunci pintu dari rancang bangun ruangan.

8. Buzzer digunakan sebagai notifikasi dalam bentuk suara. Baik pada saat akses diterima, akses ditolak, dan pada saat waktu penggunaan ruangan hampir habis.

9. Motor Servo digunakan untuk penggerak pintu pada saat membuka dan menutup.

Rancangan Perangkat Lunak

Perancangan perangkat lunak pada sistem ini adalah sebagai berikut:

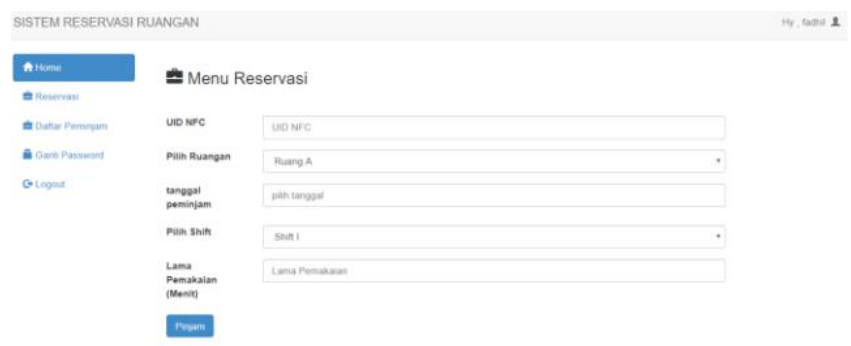

Gambar 3.3 Rancangan User Interface

Alur proses dari sistem yang dirancang secara sistematis dapat dilihat pada flowchart di bawah ini :

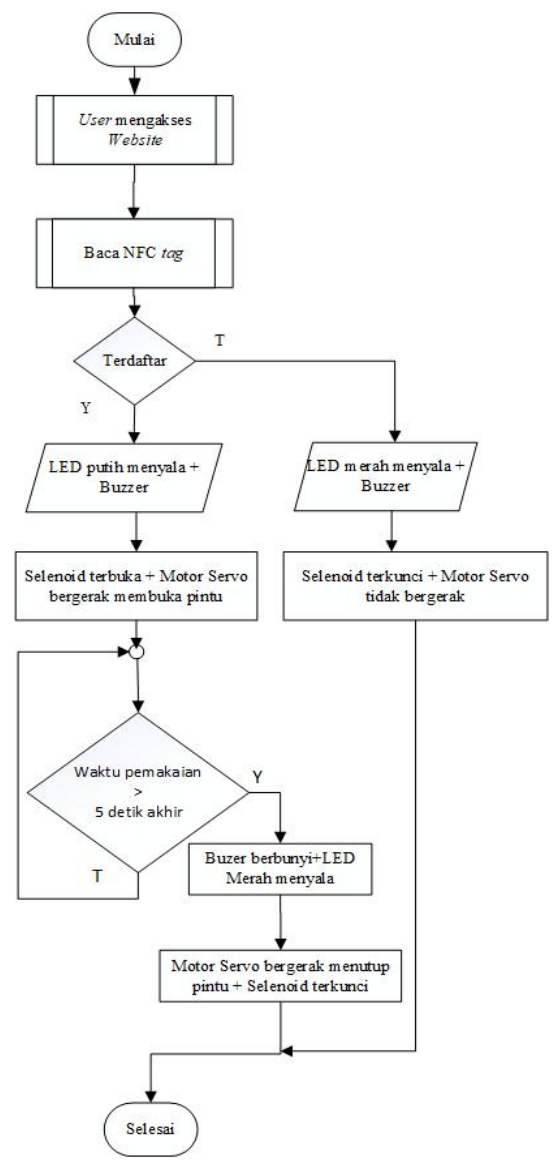

Gambar 3.4 Flowchart Rancangan Sistem 
Gambar 3.5 merupakan alur kerja dari sistem secara keseluruhan. Pertama, calon pengguna harus memiliki NFC tag terlebih dahulu. Setelah itu barulah melakukan pendaftaran pada Website. Di Website pengguna memilih ruangan yang akan dipakai, mengisi lama waktu pemakaian dan yang paling penting adalah mendaftarkan UID dari NFC yang dimilikinya. Jika telah terdaftar barulah NFC ini didekatkan pada NFC reader yang berada di pintu ruangan, maka LED putih akan menyala solenoid terbuka dan motor servo bergerak membuka pintu. Jika tidak terdaftar maka LED merah akan menyala, solenoid akan tetap terkunci dan motor servo tidak bergerak. Jika waktu lama pemakaian hamper habis maka buzzer akan berbunyi dan LED merah akan menyala. Jika waktu pemakaian telah habis, maka motor servo bergerak menutup pintu dan solenoid akan terkunci.

Pada saat user mengakses Website, terdapat beberapa fungsi yang harus dijalankan. Fungsi tersebut dapat dijelaskan dalam flowchart berikut.

Pada saat user mengakses website terdapat beberapa fungsi yang harus dijalankan, dijelaskan pada flowchart dibawah:

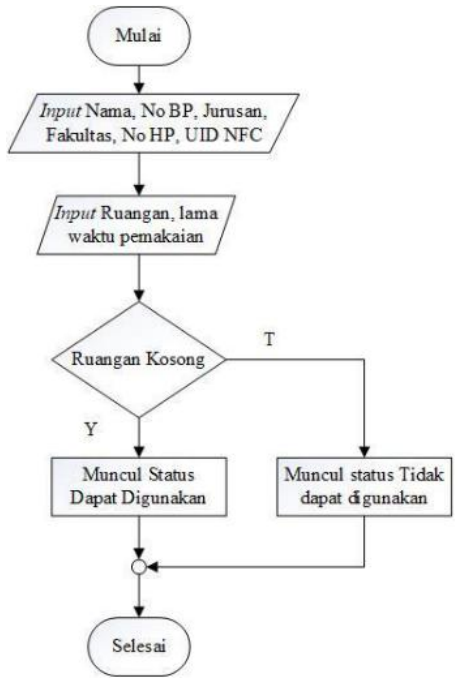

Gambar 3.5 Flowchart Pada Saat User Mengakses Website

Pertama user harus mengisi data pribadi terlebih dahulu, yakni nama, no BP, jurusan, fakultas, no hp, UID NFC yang dimiliki. Setelah itu inputkan ruangn mana yang akan digunakan beserta lama waktu peminjaman. Jika ruangan dalam keadaan kosong maka muncul notifikasi ruangan dapat digunakan, tetapi jika tidak, maka muncul notifikasi ruangan tidak dapat digunakan. Setelah mengakses Website, user harus mendekatkan NFC tag miliknya ke NFC reader yang terletak didekat pintu.

\section{Perancangan Database}

\section{Tabel User}

Pada tabel user ini menyimpan informasi mengenai user yang meliputi id user, password, nama, nim ,jurusan, fakultas, no hp. Berikut ini merupakan rancangan table user.

\section{Tabel 3. 1 Tabel User}

\begin{tabular}{|l|l|l|}
\hline Nama Field & Tipe Data & Ukuran \\
\hline Id_User & VARCHAR & 12 \\
\hline Password & VARCHAR & 12 \\
\hline Nama & VARCHAR & 40 \\
\hline Nim & VARCHAR & 10 \\
\hline Jurusan & VARCHAR & 30 \\
\hline Fakultas & VARCHAR & 30 \\
\hline No_HP & VARCHAR & 14 \\
\hline
\end{tabular}

Berdasarkan table 3.1, field Id_Ruangan merupakan primary key untuk table ruangan dengan tipe data integer. Kemudian ada Field Nama Ruangan yang memiliki tipe data varchar dengan ukuran 10. dan terakhir terdapat field Status Ruangan dengan tipe data varchar yang berukuran 20 .

\section{Tabel Reservasi}

Pada tabel reservasi, menyimpan semua informasi terkait reservasi ruangan meliputi Id reservasi, id user, tanggal peminjaman, shift, lama, Uid NFC dan ruangan.

Tabel 3. 2 Tabel Reservasi

\begin{tabular}{|l|l|l|}
\hline Nama Field & Tipe Data & Ukuran \\
\hline ID_Reservasi & INT & 11 \\
\hline ID_User & VARCHAR & 12 \\
\hline $\begin{array}{l}\text { Tanggal } \\
\text { Peminjaman }\end{array}$ & DATE & - \\
\hline Shift & VARCHAR & 10 \\
\hline \hline Lama & INT & 20 \\
\hline Ruangan & VARCHAR & 20 \\
\hline UID NFC & VARCHAR & 8 \\
\hline
\end{tabular}

Berdasarkan table 3.2, Field ID_Reservasi merupakan primary key untuk table reservasi dengan tipe data integer yang berukuran 11. Field ID user merupakan foreign key pada table reservasi karena field tersebut merupakan primary key pada tabel user. Selanjutnya terdapat field tanggal peminjaman dengan tipe data date, berikutnya field shift dengan tipe data varchar, jenis ruangan dengan tipe data varchar, dan yang terakhir field UID NFC dengan tipe data integer berukuran 8 .

\section{HASIL DAN PEMBAHASAN}

\section{Implementasi Hardware}

Implementasi perangkat keras atau hardware terdiri dari beberapa komponen yang digunakan yaitu Arduino mega, NFC reader, relay, selenoid door lock, LED, buzzer, dan miniatur ruangan. Pada Gambar 4.1 dapat dilihat dari implementasi perangkat keras yang digunakan: 


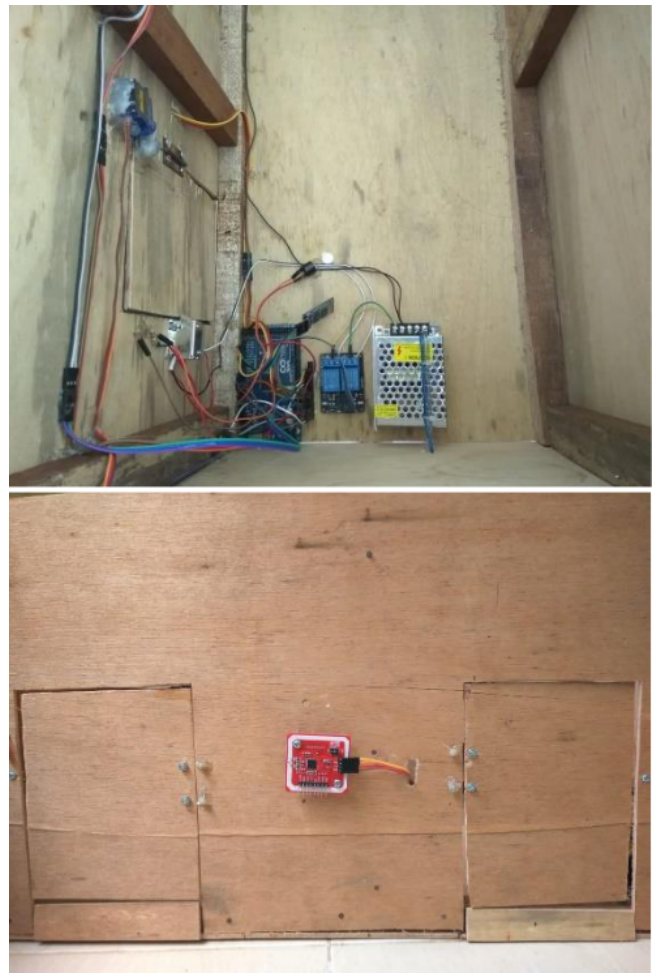

Gambar 4. 1 Implementasi Hardware

Penjelasan masing-masing komponen yang digunakan pada Gambar 4.1 adalah sebagai berikut :

1. NFC reader berfungsi sebagai pembaca UID NFC tag yang telah terdaftar pada website.

2. Arduino berfungsi untuk mengontrol buzzer, led dan relay.

3. Buzzer berfungsi untuk indikator bahwa pintu sudah terbuka dan mengeluarkan output berupa bunyi.

4. Relay berfungsi untuk mengatur arus yang masuk pada Selenoid door lock dan diprogram memasukan arus ketika UID yang terbaca sama dengan UID yang terdaftar pada website.

5. LED berfungsi untuk indikator ketika pintu sudah terbuka mengeluarkan output berupa lampu berwarna hijau dan berwarna merah ketika pintu tertutup dan juga pada saat gagal membaca UID.

6. Selenoid door lock, berfungsi untuk menjadi pengunci pintu kamar yang dikontrol oleh Arduino dan dapat terbuka jika relay memasukan arus dan tertutup jika arus dari relay hilang.

7. Motor Servo berfungsi sebagai penggerak pintu. Servo akan bergerak jika UID yang terbaca sama dengan UID yang terdaftar pada website.

\section{Implementasi Software}

Implementasi Software mencakup dua komponen, yaitu perangkat lunak tertanam yang merupakan program Arduino IDE untuk menjalankan perangkat keras dan website sebagai aplikasi sistem pemesanan ruagan dan menyimpan data pemesanan ke database.

\subsection{Implementasi Software Embeded System}

Software Embeded System merupakan program dari Arduino IDE. Program ini diimplementasikan dengan membuat baris program yang terdiri dari beberapa fungsi yang dijalankan secara berurut. Fungsi pertama yang dijalankan pada program ini adalah pembacaan UID NFC-tag, apabila UID terbaca maka fungsi selanjutnya yang dijalankan dalah fungsi pengiriman UID ke server yang terdiri dari beberapa baris program yang dimulai dengan syntax untuk menghubungkan arduino ke database, apabila berhasil terhubung maka UID akan dikirmkan ke database, sebaliknya jika gagal terhubung maka UID tidak akan diterima oleh database. Setelah berhasil terhubung maka baris program selanjutnya yang akan dijalankan adalah menggerakan pintu sesuai data ruangan yang tersimpan di database.

\subsection{Implementasi Software pada Website}

Pada website terdapat beberapa interface dan halaman yang berbeda yaitu halaman daftar, halaman home, halaman reservasi, halaman daftar peminjam, dan halaman untuk mengganti password.

a. Halaman Pendaftaran

Halaman Pendaftaran berisi form pendaftaran yang akan diisi oleh user. Dihalaman ini user diminta untuk mengisi Id user, password, nama, nim, jurusan, fakultas dan nomor HP. Pengisian form pendaftaran merupakan langkah awal yang dilakukan user untuk dapat terdaftar sebagai peminjam ruangan. Tampilan halaman pendaftaran ini adalah sebagai berikut.

\section{Masukan Data}

\begin{tabular}{|l|}
\hline ID USER \\
\hline PASSWORD \\
\hline NAMA \\
\hline JURUSAN \\
\hline FAKULTAS \\
\hline NO HP \\
\hline Daftar
\end{tabular}

Gambar 4. 2 Halaman Pendaftaran 


\section{b. Halaman Home}

Halaman home merupakan halaman awal yang muncul setelah melakukan login dengan akun yang didaftarkan pada halaman pendaftaran tadi. Halaman home ini hanya berisi kata kata sambutan kepada user.

\section{SISTEM RESERVASI RUANGAN}

\section{A Home \\ A Reservasi \\ A Daftar Peminjam \\ A Gant Password \\ G Logout}

\section{Gambar 4. 3 Halaman Home}

\section{c. Halaman Reservasi}

Halaman reservasi merupakan halaman tempat user melakukan pemesanan ruangan. Pada halaman ini user akan memasukan uid dari NFC yang dimiliki, memilih ruangan yang akan digunakan, memasukan tanggal pemakaian, memilih shift, dan memasukan lama pemakaian. Setelah selesai diisi barulah user menekan tombol pinjam sebagai bentuk finalisasi peminjaman ruangan.

\section{d. Halaman Daftar Peminjam}

Halaman daftar peminjam berfungsi menampilkan informasi peminjam ruangan. Informasi yang ditampilkan didalam halaman ini adalah nama, nim, jurusan, ruangan, tanggal, shift, lama pemakaian dan UID yang didaftarkan.

\section{SISTEM RESERVASI RUANGAN}

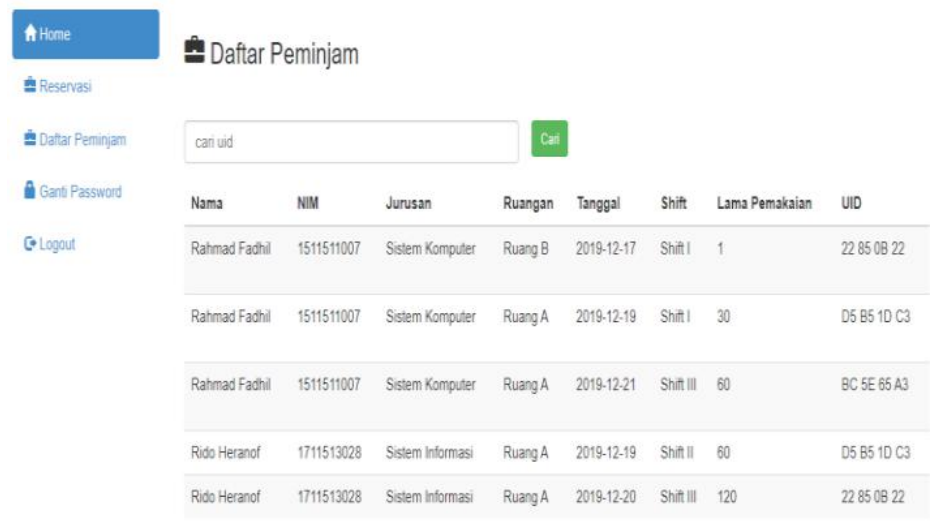

Gambar 4. 5 Halaman Daftar Peminjam

e. Halaman Ganti Password

Halam ganti password berfungsi untuk mengganti password user. Pada halaman ini user meginputkan password lama terlebih dahulu setelah itu baru menginput password baru.

\section{SISTEM RESERVASI RUANGAN}

A Home
Reservasi
Daftar Peminjam
C. Lanti Password

Gambar 4. 6 Halaman Ganti Password 


\section{Implementasi Sistem secara Keseluruhan}

Implementasi sistem secara keseluruhan merupakan gabungan dari implementasi perangkat keras dan implementasi perangkat lunak. Sistem ini dapat melakukan pemesanan ruangan dengan cara mendaftarkan UID NFCtag yang digunakan untuk membuka pintu ruangan dengan cara mendekatkan NFCtag ke pada NFC scan pada webcam yang tersedia didepan pintu kamar hotel ketikreadre yang terletak didekat pintu ruangan. Jika UID terdaftar sesuai dengan UID yang tersimpan di database maka selenoid akan membuka kunci kamar, led putih menyala dan servo bergerak membuka pintu. Namun jika UID tidak sesuai maka led merah akan menyala dan buzzer akan berbunyi.

\section{Pengujian dan Analisa}

Pengujian dilakukan untuk mengetahui apakah setiap komponen pada sistem telah bekerja seperti yang diharapkan. Lalu dari hasil pengujian tersebut dilakukan analisa system secara keselurahan. Pada tahap ini terdapat tiga rangkaian pengujian yang akan dilakukan yaitu pengujian dan analisa perangkat keras, pengujian dan analisa perangkat lunak, dan pengujian dan anlisa secara keseluruhan.

\subsection{Pengujian dan Analisa Hardware \\ 2.1.1 Pengujian Pembacaan NFC-tag}

Pengujian pembacaan NFC-tag dilakukan untuk mengetahui berapa jarak minimal dan maksimal pembacaan NFC-tag oleh NFC-reader. Pengujian ini dilakukan dengan cara mendekatkan NFC-tag ke NFC-reader

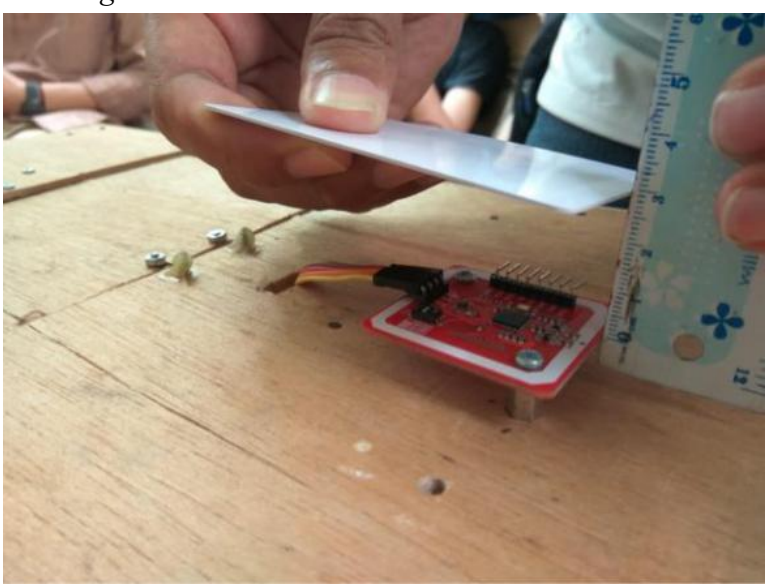

Gambar 4. 7 Pengujian Pembacaan NFC-tag Oleh NFC-reader Dari pengujian ini didapatkan jarak baca minimum dan maksimum NFC-reader terhadap NFC-tags eperti pada Tabel 4.1 berikut:

Tabel 4.1 Pengujian pembacaan jarak NFC-Tag oleh NFC-Reader

\begin{tabular}{|l|l|}
\hline Jarak $(\mathrm{Cm})$ & Hasil Pengujian \\
\hline 1,0 & Terdeteksi \\
\hline 1,5 & Terdeteksi \\
\hline 2,0 & Terdeteksi \\
\hline 2,5 & Terdeteksi \\
\hline 3,0 & Terdeteksi \\
\hline 3,5 & Tidak Terdeteksi \\
\hline
\end{tabular}

Hasil pengujian yang telah dipaparkan pada tabel 4.1 adalah pembacaan maksimal NFC tag oleh NFC-reader yaitu $3 \mathrm{~cm}$. Ketika NFC-tag didekatkan pada jarak diatas $3 \mathrm{~cm}$ maka NFCreader tidak dapat membaca NFC-tag tersebut.

\section{Pengujian Motor Servo}

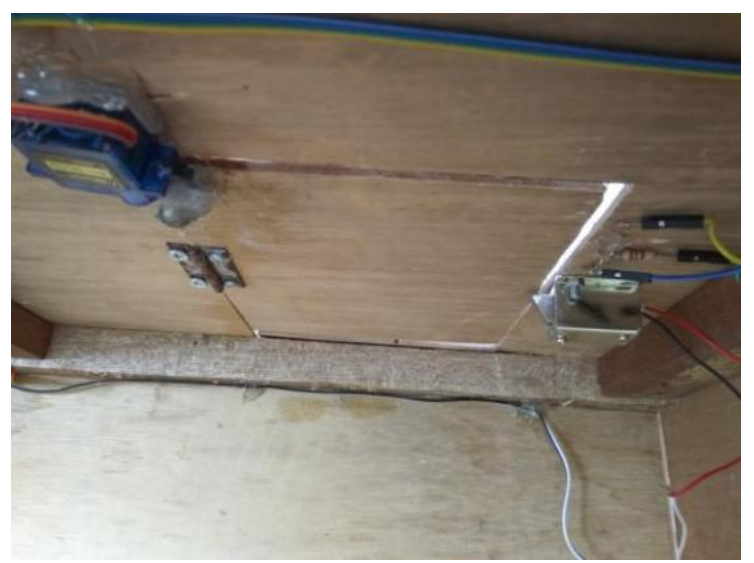

\section{Gambar 4. 8 Motor Servo Menutup Pintu}

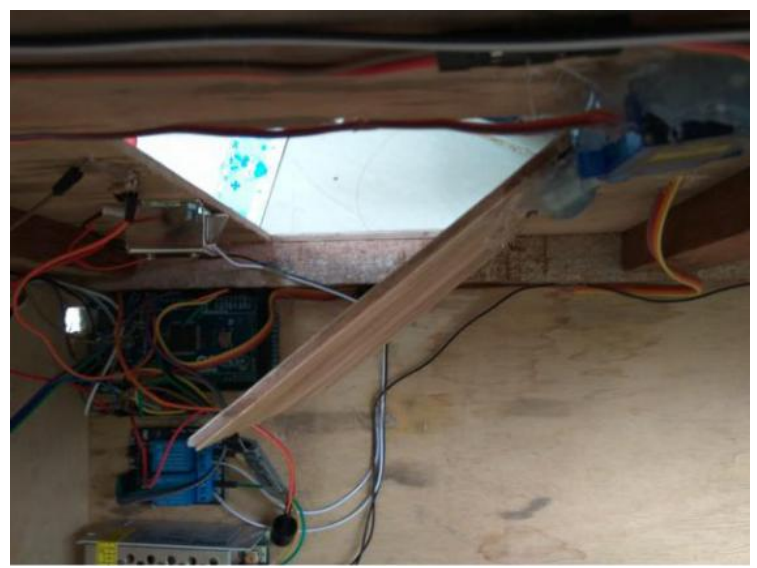

Gambar 4. 9 Motor servo Membuka Pintu

Hasil dari pengujian motor servo ini dapat dilihat pada tabel 4.2.

Tabel 4. 2 Pengujian Motor Servo

\begin{tabular}{|l|l|l|}
\hline Percobaan & Besar Sudut & Keadaan Pintu \\
\hline 1 & $0^{\circ}$ & Tertutup \\
\hline 2 & $10^{\circ}$ & Terbuka \\
\hline 3 & $20^{\circ}$ & Terbuka \\
\hline 4 & $30^{\circ}$ & Terbuka \\
\hline 5 & $40^{\circ}$ & Terbuka \\
\hline
\end{tabular}

Pada pengujian motor servo tabel 4.2 dilakukan pengujian sudut hingga pintu terbuka. Pada sudut besar dar 0 motor servo akan bergerak dan pintu terbuka.

\section{Pengujian Bluetooth}

Pengujian bluetooth dilakukan untuk mengetahui waktu dan jarak sebagai indikator uji yang diperlukan untuk mengirim data UID yang telah diproses pada mikrokonteroler menuju smartphone. Waktu yang diperlukan untuk mengirim data dari pernagkat menuju smartphone dilakukan pengujian guna mendapatkan data waktu kirim antara satu data dengan data lainnya.

Tabel 4.3 Pengujian Bluetooth

\begin{tabular}{|l|l|}
\hline Pengujian & Waktu Respon \\
\hline 1 & 1,4 \\
\hline 2 & 1,4 \\
\hline 3 & 1.5 \\
\hline 4 & 1,5 \\
\hline 5 & 1,3 \\
\hline 6 & 1,3 \\
\hline 7 & 1,3 \\
\hline 8 & 1,4 \\
\hline
\end{tabular}




\begin{tabular}{|l|l|}
\hline 9 & 1,6 \\
\hline 10 & 1,6 \\
\hline
\end{tabular}

Dari sepuluh percobaan yang dilakukan pada pengujian ini, didapat nilai waktu respon yang bervariasi namun perbedaan nilainya tidak terlalu signifikan, respon terlama yang diperoleh adalah 1.6 detik dan waktu respon tercepat yang didapat adalah 1.3 detik. Rata-rata waktu respon bluetooth yang diperoleh mulai pengiriman UID ke server hingga diterima respon balik dari server adalah sebesar 1.43 detik.

\section{Pengujian LED dan Buzzer}

Pengujian terhadap perangkat LED dan Buzzer ini dilakukan untuk menguji kesesuaian tampilan infomasi yang ditampilkan oleh LED dan Buzzer dengan masukkan yang telah diberikan. LED yang digunakan pada sistem ini berwarna merah dan putih. Pada sistem ini LED berfungsi untuk menampilan informasi tap NFC dan informasi akses diterima atau akses ditolak. LED dan Buzzer menampilkan informasi terhadap keberhasilan akses pintu otomatis setelah NFC-tag berhasil dibaca oleh NFC-reader. Dari pengujian yang telah dilakukan LED berhasil menampilkan informasi yang sesuai dengan masukkan yang diberikan.

\section{Pengujian dan Analisa Selenoid Door Lock}

Pengujian solenoid door lock pada tanggal 29/10/2019 bertujuan untuk mengetahui respon solenoid saat menerima inputan $Q R$ code yang valid yaitu ketika tanggal yang terdaftar sama dengan tanggal sekarang. Hasil daripada penelitian dapat dilihat pada Tabel 4.10 berikut:

Tabel 4.4 Hasil Pengujian Selenoid Door Lock yang Memenuhi Syarat Buka Pintu

\begin{tabular}{|l|l|l|}
\hline $\begin{array}{l}\text { Percobaan } \\
\text { Ke- }\end{array}$ & $\begin{array}{l}\text { Respon Solenoid } \\
\text { Kamar Superior }\end{array}$ & $\begin{array}{l}\text { Respon Solenoid } \\
\text { Kamar Deluxe }\end{array}$ \\
\hline 1 & $H I G H$ & $H I G H$ \\
\hline 2 & $H I G H$ & $H I G H$ \\
\hline 3 & $H I G H$ & $H I G H$ \\
\hline 4 & $H I G H$ & $H I G H$ \\
\hline 5 & $H I G H$ & $H I G H$ \\
\hline 6 & $H I G H$ & $H I G H$ \\
\hline 7 & $H I G H$ & $H I G H$ \\
\hline 8 & $H I G H$ & $H I G H$ \\
\hline 9 & $H I G H$ & $H I G H$ \\
\hline 10 & $H I G H$ & $H I G H$ \\
\hline Total Keberhasilan & $100 \%$ \\
\hline
\end{tabular}

Dalam Kondisi HIGH Inti besi dari Selenoid doorlock tertarik kedalam karena menerima arus dari relay menyebabkan pintu dapat dibuka.

Pengujian dilakukan dengan memesan 2 kamar dengan 2 nama berbeda pada tanggal 16/12/2019 berhasil membuka pintu kamar dengan persentase keberhasilan 100\%. Dapat disimpulkan bahwa respon Selenoid door lock dalam menerima inputan dari mikrokontroler sesuai dengan target penelitian.

Tabel 4. 5 Hasil Pengujian Selenoid Door Lock yang Tidak Memenuhi Syarat Buka Pintu

\begin{tabular}{|l|l|l|}
\hline $\begin{array}{l}\text { Percobaan } \\
\text { Ke- }\end{array}$ & $\begin{array}{l}\text { ResponSolenoid } \\
\text { Kamar Superior }\end{array}$ & $\begin{array}{l}\text { Respon Solenoid } \\
\text { Kamar Deluxe }\end{array}$ \\
\hline 1 & LOW & LOW \\
\hline 2 & LOW & LOW \\
\hline 3 & $L O W$ & LOW \\
\hline 4 & $L O W$ & LOW \\
\hline 5 & $L O W$ & LOW \\
\hline 6 & $L O W$ & $L O W$ \\
\hline 7 & $L O W$ & $L O W$ \\
\hline 8 & $L O W$ & $L O W$ \\
\hline 9 & $L O W$ & $L O W$ \\
\hline 10 & $L O W$ & $L O W$ \\
\hline Total Keberhasilan & $100 \%$ \\
\hline
\end{tabular}

Dalam Kondisi $L O W$ Inti besi dari Selenoid doorlock tertarik kedalam karena tidak menerima arus dari relay yang menyebabkan pintu tidak dapat dibuka.

Pengujian dilakukan pada tanggal 16/12/2019 dengan melakukan pembacaa UID NFC yang tidak terdaftar. Tidak satupun NFC yang berhasil membuka pintu, maka persentase keberhasilan ketika NFC tag yang UID tidak terdaftar di baca ole NFC reader sebesar 100\%. Dapat disimpulkan bahwa respon Selenoid doorlock dalam menerima inputan dari mikrokontroler sesuai dengan target penelitian.

\section{Pengujian dan Analisa Software \\ 1 Pengujian Validasi}

Pengujian validasi dilakukan untuk mengetahui apakah aplikasi web yang dibangun sudah berjalan sesuai hasil yang diharapkan. Pada pengujian ini metode yang digunakan adalah metode black box, yaitu pengujian dengan cara melihat kesesuaian proses dan hasil yang diinginkan. Berikut hasil dari pengujian validasi

\subsection{Hasil Pengujian Validasi}

\begin{tabular}{|c|c|c|c|}
\hline No. & Proses & Hasil yang diharapkan & $\begin{array}{l}\text { Status } \\
\text { Validasi }\end{array}$ \\
\hline 1 & $\begin{array}{l}\text { Halaman } \\
\text { Pendaftaran }\end{array}$ & $\begin{array}{l}\text { Website mampu } \\
\text { melakukan } \\
\text { pendaftaran user } \\
\text { sebagai pengguna. }\end{array}$ & Berhasil \\
\hline 2 & Login & $\begin{array}{lr}\text { Website } & \text { mampu } \\
\text { menerima } & \text { inputan } \\
\text { Login } & \text { dengan } \\
\text { username } & \text { dan } \\
\text { password yang } & \text { sesuai. }\end{array}$ & Berhasil \\
\hline 3 & $\begin{array}{l}\text { Halaman } \\
\text { Reservasi }\end{array}$ & $\begin{array}{l}\text { Website mampu } \\
\text { memesan ruangan dan } \\
\text { membuka pintu sesuai } \\
\text { jenis ruangan dan lama } \\
\text { pemakaian yang } \\
\text { ditentukan. }\end{array}$ & Berhasil \\
\hline 4 & $\begin{array}{ll}\text { Halaman } & \text { Daftar } \\
\text { Peminjam } & \end{array}$ & $\begin{array}{l}\text { Website } \quad \text { mampu } \\
\text { menampilkan banyak } \\
\text { user yang memnjam } \\
\text { ruangan. }\end{array}$ & Berhasil \\
\hline 5 & Hapus jadwal & $\begin{array}{lr}\text { Website } & \text { mampu } \\
\text { menghapus } & \text { jadwal } \\
\text { yang telah } & \text { berhasil } \\
\text { direservasi. } & \end{array}$ & Berhasil \\
\hline 6 & $\begin{array}{ll}\text { Halaman } & \text { Ganti } \\
\text { Password } & \end{array}$ & $\begin{array}{lr}\text { Website } & \text { mampu } \\
\text { mennganti } & \text { password }\end{array}$ & Berhasil \\
\hline
\end{tabular}




\begin{tabular}{|l|l|l|}
\hline & $\begin{array}{l}\text { yang sedang digunakan } \\
\text { dengan password yang } \\
\text { baru. }\end{array}$ & \\
\hline
\end{tabular}

Berdasarkan tabel hasil pengujian validasi diatas maka dapat disimpulkan bahwa segala proses yang terdapat di dalam perangkat lunak Website reservasi ruangan secara online yang telah dibangun memiliki tingkat keberhasilan 100\% dan mencapai hasil yang diharapkan.

2 Pengujian Kecocokan Database MySQL dengan Website Pengujian Database MySQL ini merupakan pengujian yang dilakukan untuk mengetahui apakah data yang diinputkan melalui form pada website sesuai dengan data yang tersimpan didalam database MySQL. Data yang tersimpan di dalam database MySQL menggunakan sistem tabel yang sudah disesuaikan dengan form yang akan diisi oleh peminjam ruangan. Hal ini menyebabkan proses pertukaran data lebih cepat. Berikut tampilan form pada halaman website dan Database MySQL:

\section{Masukan Data}

\begin{tabular}{|l|}
\hline Akbar \\
karim 123 \\
\hline Akbar Karim \\
IImu Politik \\
IImu Sosial Dan Poltik \\
|081266567823 \\
Daftar \\
\hline
\end{tabular}

Gambar 4. 10 Tampilan Form Pendaftaran Yang Sudah Diisi

Form yang telah diisi pada Gambar 4.11 akan dicocokan dengan data pada tabel user database MySQL.

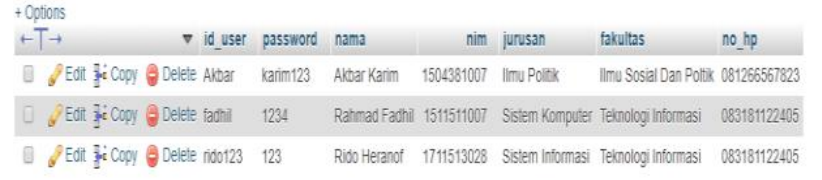

Gambar 4. 11 Tampilan tabel User pada database MySQL

Pada Gambar 4.11 menunjukkan bahwa form yang diisi peminjam ruangan pada website berupa Username, Password, Nama, Nim, Jurusan, Fakultas, No hp cocok dengan apa yang ditampilkan di database MySQL.

\section{Menu Reservasi}

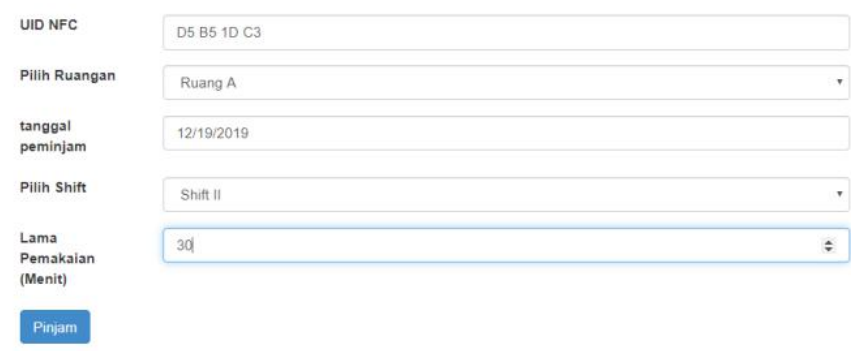

Gambar 4. 12 Tampilan Form Reservasi Yang Sudah Diisi.
Pada Gambar 4.13 menunjukkan bahwa form reservasi yang diisi akan dicocokan dengan data pada tabel reservasi database MySQL.

\begin{tabular}{|c|c|c|c|c|c|c|}
\hline$\leftarrow$ & $\rightarrow$ & $\nabla$ & id_reservasi & id_user & tanggal_peminjaman & shift \\
\hline$\square$ & Edit ?atic Copy & (2) Delete & 95 & fadhil & $2019-12-17$ & Shift I \\
\hline D & Edit ¥̧; Copy & (2) Delete & 96 & fadhil & 2019-12-19 & Shift I \\
\hline$\square$ & Edit 率: Copy & (2) Delete & 97 & fadhil & $2019-12-21$ & Shift II \\
\hline$\square$ & Edit द्रें Copy & (2) Delete & 98 & rido123 & 2019-12-19 & Shift II \\
\hline$\square$ & Edit Fis Copy & (2) Delete & 99 & rido123 & $2019-12-20$ & Shift II \\
\hline
\end{tabular}

Gambar 4. 13 Tampilan Tabel Reservasi Pada Database MySQL

Pada gambar 4.14 Peminjam ruangan menginputkan pada website berupa UID NFC, Jenis Ruangan, Tanggal Peminjaman, Shift, Lama Pemakaian, cocok dengan apa yang ditampilkan di database MySQL.

Tabel 4. 6 Pengujian Kecocokan Form Website dengan Database

\begin{tabular}{|c|c|c|c|c|c|c|c|}
\hline Nama & Id User & $\begin{array}{c}\text { Tanggal } \\
\text { pinjam }\end{array}$ & Shift & lama & UID NFC & $\begin{array}{c}\text { Jenis } \\
\text { Ruangan }\end{array}$ & $\begin{array}{c}\text { Validasi } \\
\text { MySQL }\end{array}$ \\
\hline Fadhil & Fadhil & $\begin{array}{c}21-12- \\
2019\end{array}$ & III & 60 & BC 5E 65 A3 & A & $\checkmark$ \\
\hline Ridho & Ridho123 & $\begin{array}{c}20-12- \\
2019\end{array}$ & III & 120 & 22 85 0B 22 & A & $\checkmark$ \\
\hline Aakbar & akbar & $\begin{array}{c}18-12- \\
2019\end{array}$ & I & 30 & D5 B5 1D C3 & A & $\checkmark$ \\
\hline
\end{tabular}

Pada Tabel 4.6 dilakuakan pengujian dengan mengisi form pada website lalu di validasi dengan melihat isi tabel reservasi pada database MySQ. Data pengguna ruangan yang ditampilkan diatas memiliki tingkat kesesuaian $100 \%$ dengan data yang diinputkan melalui website.

1. 4.2.3 Pengujian dan Analisa Keseluruhan

Pengujian sistem secara keseluruhan dilakukan untuk melihat kemampuan sistem yang dibangun dalam menghasilkan keluaran yang sesuai dengan hasil yang diharapkan. Berikut langkahlangkah yang dilakukan dalam pengujian sistem secara keseluruhan :

1. Pengguna ruangan terlebih dahulu harus mengakses website reservasi ruangan melalui browser pada smartphone, laptop atau PC.

2. Pengguna ruangan harus mengisi form pendaftaran yang disediakan untuk mendafarkan diri sebagai pengguna. Tidak boleh kosong satu data pun.

3. Setelah melakukan pendaftaran maka pengguna akan login dengan username dan password yang telah terdaftar.

4. Pengguna ruangan harus melakukan reservasi ruangan sesuaii dengan jenis ruangan yang dipilih dan meninputkan lama pemakaian.

5. Setelah reservasi ruangan berhasil maka pengguna ruangan akan terdaftar sebagai pengguna, hal ini dibuktikan dengan terdaftar pada halaman daftar peminjam.

6. Pengguna ruangan datang ke ruangan dengan membawa NFC tag yang akan di-dekatkan langsung pada NFC reader didepan pintu ruangan untuk memverifikasi apakah pengguna tersebut memiliki akses untuk membuka pintu ruangan.

7. Jika UID yang dimiliki pengguna ruangan cocok dengan yang ada pada database maka sistem akan mengeluarkan output berupa solenoid bernilai $H I G H$, motor servo 
bergerak sehingga pintu terbuka dan LED putih akan menyala.

8. ketika waktu pemakaian habis maka motor servo akan bergerak menutup pintu dan solenoid bernilai $L O W$ maka pintu akan terkunci.

Pengujian ini dilakukan dengan 5 kali percobaan dan melibatkan 5 user yang berbeda. Pengujian dilakukan pada tanggal 16/12/2019 dengan hasil pengujian sistem secara keseluruhan ini dapat dilihat pada Tabel 4.7 berikut:

Tabel 4. 7 Pengujian Sistem Secara Keseluruhan

\begin{tabular}{|c|l|l|c|c|c|c|c|}
\hline No & Nama & $\begin{array}{c}\text { Tanggal } \\
\text { Check } \text { in }\end{array}$ & $\begin{array}{c}\text { Pembacaan } \\
\text { UID NFC }\end{array}$ & $\begin{array}{c}\text { Kondisi } \\
\text { Selenoid }\end{array}$ & $\begin{array}{c}\text { Motor } \\
\text { Servo }\end{array}$ & LED & Status \\
\hline 1. & Fadhil & $\begin{array}{l}21-12- \\
2019\end{array}$ & Terdaftar & HIGH & Begerak & Putih & Sesuai \\
\hline 2. & Ridho & $\begin{array}{l}20-12- \\
2019\end{array}$ & Terdaftar & HIGH & Begerak & Putih & Sesuai \\
\hline 3. & Akbar & $\begin{array}{l}18-12- \\
2019\end{array}$ & Terdaftar & HIGH & Begerak & Putih & Sesuai \\
\hline 4. & kevin & $10 / 28 / 2019$ & $\begin{array}{c}\text { Tidak } \\
\text { Terdaftar }\end{array}$ & LOW & Diam & Merah & Sesuai \\
\hline 5. & Ilham & $\begin{array}{c}\text { Tidak } \\
\text { Terdaftar }\end{array}$ & LOW & Diam & Merah & Sesuai \\
\hline 6. & Mario & $12 / 30 / 2019$ & $\begin{array}{c}\text { Tidak } \\
\text { Terdaftar }\end{array}$ & LOW & Diam & Merah & Sesuai \\
\hline
\end{tabular}

Pengujian sistem secara keseluruhan pada sistem ini telah berhasil dilakukan dengan 6 kali percobaan menggunakan 6 nama pengguna ruanga yang berbeda-beda. Dari hasil pengujian keseluruhan sistem ini didapatkan persentase keberhasilan pengujian sebesar : $100 \%^{-}$

Hasil ini menunjukkan bahwa sistem dapat berjalan sesuai dengan fungsinya dan sistem dapat menghasilkan keluaran sesuai dengan hasil yang diharapkan.

\section{KESIMPULAN}

Berdasarkan penelitian dan pengujian yang dilakukan, dapat disimpulkan bahwa :

1. Sistem sudah dapat memesan ruangan secara online dengan persentase keberhasilan $100 \%$.

2. Pendaftaran NFC Tag ke masing-masing ruang kelas yang dipilih sudah berhasil dengan tingkat keberhasilan $100 \%$.

3. Jarak untuk pembacaan NFC tag oleh NFC reader adalah 1-3 cm, jika melebihi jarak itu makan UID tidak terbaca oleh NFC reader. Kecepatan rata-rata dari pembacaa NFCtag oleh reader adalah 3,032 detik.

4. Pada system ini menggunakan media pengirim berupa Bluetooth HC-05 dengan waktu respon rata-rata adalah 1,43 detik.

5. Solenoid door lock dapat membuka pintu ruangan ketika UID yang terbaca sama dengan UID yang terdaftar pada database.

6. Solenoid door lock dapat bergerak ketika mendapat arus dari relay, jika tidak maka tidak akan bergerak.

7. Website dapat memberikan notifikasi pada saat ruangan sudah dipinjam pada shift dan tanggal yang sama dengan persentase keberhasilan $100 \%$
8. Sistem ruangan dapat memeberikan notifikasi berupa buzzer berbunyi dengan persentase keberhasilan 100\%.

\section{REFERENCES}

[1]Hung, Chi-Huang, Ying-en Bai, Je-Hong Ren. 2015. "Design and Implementation of a Door Lock Control Based on a Near Field Communication of a Smartphone". International Conference on Consumer Electronics : Berlin. 15 (5) : 4799-8748

[2]Windarto, Yudi Eko, Dania Eridani. 2017. "Door And Light Control Prototype Using Intel Galileo Based Internet of Things". International Conference on Information Technologi, Computer, and Electrical Engineering : Semarang. 17(4) : 3947-5386

[3]Fajri, Haditiya. 2016. "Sistem Monitoring Kunci Pintu Ruangan". Skripsi Sarjana pada Sistem Komputer Universitas Andalas : Padang

[4]Kurniawan, Hendra. 2011.”Pengembangan Sistem Manajemen Reservasi Ruangan Online Dengan ZK Ajak Framework". Skripsi. Program studi Teknik Informatika Fakulta Sains dan Teknologi Universitas Syarif Hidayatullah : Jakarta

[5]Putri, Anissa Yolanda, Dodon Yendri. 2018. Sistem Pemesanan Makanan dan Minuman pada Restoran Menggunakan Teknologi NFC Berbasis Android. Journal of Information Technology and Computer Engineering. 2(1): 34-40

[6]Arief Dharmawan, Hari. 2017. Mikrokontroler Konsep Dasar dan Praktis. Malang: UBMedia

[7]Mercubuana "Buzzer" Repository. dalam http://digilib.its.ac.id/public/ITSUndergraduate-10137-Chapter1.pdf

[8]Kho, Dickson. 2017. Pengertian LED(Light Emitting Diode) dan Cara Kerjanya. Dalam http://teknikelektronika.com/pengertian-ledlightemitting-diode-cara-kerja/. Diakses pada tanggal 19 Februari 2019 pukul 11.16 WIB.

[9]SinauArduino. 2016. Mengenal Arduino Software (IDE), dalam https://www.sinauarduino.com/artikel/mengenal-arduino-software-ide/ diakses pada tanggal 16 Februari 2019 pukul 14.03 WIB

[10]Solichin, Achmad. 2010. MySQL 5, dari Pemula hingga Mahir. Achmatim.net: Jakarta.

[11]Yendri, Dodon, Rahmi Eka Putri. 2018. Sistem Pengontrolan Dan Keamanan Rumah Pintar (Smart Home) Berbasis Android. Journal of Information Technology and Computer Engineering. 2(1) : 1-6

[12]Sujarwata. 2013. Pengendali Motor Servo Berbasis Mikrokontroler Basic stamp 2sx untuk Mengembangkan Sistem Robotika. Universitas Negeri Semarang 